\title{
NOVÝ SEVEROKOREJSKÝ JADERNÝ TEST A ROLE STANICE VRAC V RÁMCI MEZINÁRODNÍHO MONITOROVACÍHO SYSTÉMU CTBTO
}

\author{
New North Korean nuclear test and role of the station VRAC in the framework \\ of the International Monotoring System of the CTBTO
}

Josef Havír

Ústav fyziky Země, PřF MU, Tvrdého 12, 60200 Brno; e-mail: havir@ipe.muni.cz

Key words: seismic monitoring, CTBTO, nuclear explosions, station VRAC

\begin{abstract}
Many seismological stations situated all round the world have registered seismic signal related to North Korean nuclear test explosion conducted on 6th January 2016. Good seismic record was provided also by station VRAC operated by IPE (Institute of Physics of the Earth) which is part of the International monitoring system CTBTO focused on the verification of the compliance with the Comprehensive Nuclear-Test-Ban Treaty. Seismic network of the International monitoring system CTBTO is composed of 170 seismic stations. Data are transmitted into International Data Centre in Vienna. In the IPE, Czech "National Data Centre" (NDC) is established, which is responsible for operation of station VRAC and technical information of state authorities. Czech NDC provides also independent data processing of important seismic events, such as the Korean nuclear test. Results of seismic data processing prove very close position of epicentre of the discussed explosion in comparison to previous North Korean nuclear tests conducted in 2006, 2009 and 2013 at the nuclear test site Punggye-ri. Calculated values of body wave magnitude mb (the body wave magnitude $\mathrm{mb}$ reaches value from 4.8 according IDC CTBTO to 5.1 according U. S. seismological survey NEIC) show, that yield of the 2016 test explosion is probably slightly lower relative to the 2013 nuclear test.
\end{abstract}

Dne 6. ledna 2016 byl na severokorejském jaderném polygonu Punggye-ri uskutečněn nový jaderný test. Seismický signál související s tímto testem byl zaznamenán řadou seismologických stanic po celém světě. Velmi dobře byl registrován stanicemi situovanými v Evropě, mimo jiné také stanicí VRAC (Vranov u Brna) provozovanou Ústavem fyziky Země (ÚFZ) Masarykovy University v Brně. Stanice VRAC i datové centrum provozované na ÚFZ Brno je součástí Mezinárodního monitorovacího systému Organizace smlouvy o všeobecném zákazu jaderných zkoušek (Comprehensive Nuclear-Test-Ban Treaty Organisation - CTBTO). Tato zařízení proto mají tedy v rámci monitorování jaderných explozí určitou výjimečnou roli. Cílem tohoto článku je stručně informovat jak o zmíněné roli stanice VRAC, tak i o parametrech letošního severokorejského jaderného testu zjištěných na základě seismologických dat.

\section{Stanice VRAC a Mezinárodní monitorovací systém CTBTO}

Dlouhodobé snahy o zastavení či alespoň omezení jaderných experimentů vyvrcholily předložením Smlouvy o úplném zákazu jaderných zkoušek (Comprehensive Nuclear-Test-Ban Treaty) Valnému shromáždění OSN v září 1996. Česká republika tuto smlouvu podepsala již 12. 11. 1996 a ratifikovala 11.9. 1997. Do této chvíle smlouvu CTBT podepsalo 183 států a $164 \mathrm{z}$ nich ji ratifikovalo.

Součástí smlouvy je také vybudování a provozování celosvětového monitorovacího systému, který by byl schopen sledovat dodržování smlouvy. Hlavním úkolem Mezinárodního monitorovacího systému CTBTO je tedy zaregistrovat a určit polohu takových jevů, které by moh- ly souviset $s$ případným uskutečněním jaderného testu kdekoli na povrchu Země. Pro monitorovací systém byly vybrány čtyři technologie, a to seismická, infrazvuková, hydroakustická a radionuklidová (Hoffmann et al. 1999). Zásadní roli při detekci a lokalizaci jevu hraje metoda seismického monitorování (viz např. Bowers - Selby 2009). Seismická sit Mezinárodního monitorovacího systému má sestávat $\mathrm{z}$ celkem 170 stanic. Z nich má být 50 tzv. primárních stanic (primary stations), určených k primární automatické detekci jevů, a 120 tzv. pomocných stanic (auxiliary stations), jejichž data jsou nezbytná k přesnému určení parametrů (lokace, magnitudo apod.) detekovaného seismického jevu. V tuto chvíli má seismická sít Mezinárodního monitorovacího systému CTBTO instalováno a certifikováno 42 primárních a 107 pomocných stanic.

Data všech stanic Mezinárodního monitorovacího systému CTBTO jsou přenášena satelitním spojením do Mezinárodního datového centra (International Data Centre - IDC) ve Vídni, kde jsou následně vyhodnocována. Každoročně je v IDC zpracováno více než 30000 jevů zaregistrovaných seismickou sítí Mezinárodního monitorovacího systému CTBTO.

Jednou z pomocných stanic seismické sítě Mezinárodního monitorovacího systému CTBTO je také stanice VRAC situovaná u Vranova u Brna. Stanice VRAC je v provozu od roku 1990, do Mezinárodního systému CTBTO byla zařazena jako pomocná stanice AS26 již od roku 1996 a certifikována byla v roce 2002, po dokončení modernizace přístrojového vybavení (Havíř a kol. 2003). Registrace seismického signálu je na stanici VRAC zajištěno širokopásmovým seismometrem STS-2 high gain a digitizérem Quanterra Q330, což umožňuje monitorová- 
ní v širokém rozmezí frekvencí od lokálních po vzdálené (teleseismické) jevy. Záznamy stanice VRAC je tak možné rutinně využívat pro seismické monitorování na lokální, regionální i globální úrovni. Počet jevů zaregistrovaných stanicí VRAC během jednoho roku se pohybuje většinou $\mathrm{v}$ rozmezí od jednoho do dvou tisíc.

Za technické zajištění provozu stanic zodpovídají tzv. Národní datová centra (National Data Centre - NDC). České NDC zřízené v rámci struktury Mezinárodního monitorovacího systému CTBTO je umístěno na Ústavu fyziky Země v Brně. Jeho úkolem je nejen zajištovat bezporuchový kontinuální provoz stanice VRAC, ale také informovat Státní úřad pro jadernou bezpečnost (SÚJB) o významných skutečnostech týkajících se globálního monitorování prováděného $\mathrm{v}$ rámci CTBTO. Informace o seismických jevech souvisejících s jadernými testy patří, pochopitelně, k těm nejvýznamnějším ze sledovaných skutečností. Seismické záznamy jaderné exploze provedené 6. 1. 2016 v Severní Koreji proto byly nezávisle zpracovány také v NDC v Brně, podobně jako v minulých letech záznamy předchozích korejských jaderných testů (Havír 2013), a výsledky zpracování byly průběžně poskytovány pro potřeby SÚJB.

Zpracování záznamů severokorejského testu z 6. 1.2016

Pro určení parametrů zdroje seismického signálu byla v NDC v Brně v př́padě severokorejského jaderného testu ze dne 6. 1. 2016 využita data celkem 58 stanic situovaných v různých částech světa (obr. 1), v epicentrálních vzdálenostech od $3^{\circ}$ do $95^{\circ}$ od severokorejského jaderného polygonu (viz obr. 2). Kromě stanice VRAC a dalších širokopásmových stanic provozovaných Ústavem fyziky Země byly zpracovány také záznamy ostatních seismických stanic Mezinárodního monitorovacího systému CTBTO. Datový soubor byl doplněn také o dostupné záznamy dalších vhodně umístěných stanic provozovaných jinými seismologickými organizacemi.

Poloha epicentra otřesu spojeného se severokorejským jaderným testem ze dne 6. 1. 2016 určená v NDC v Brně byla $41.30^{\circ}$ severní šířky a $129.07^{\circ}$ východní délky. Odchylka polohy epicentra určené v NDC v Brně od bodů určených nezávisle $\mathrm{v}$ IDC CTBTO a v datovém centru seismologické služby USA (NEIC) nepřesáhla hodnotu dvou kilometrů. Rozdíly mezi zmíněnými nezávisle určenými polohami epicentra jsou mnohem menší než délka poloos chybové elipsy a jsou tak výrazně pod úrovní chyby výpočtu.

Magnitudo mb určené $\mathrm{z}$ amplitud objemových vln bylo $\mathrm{v}$ NDC $\mathrm{v}$ Brně počítáno pouze ze záznamů širokopásmových stanic provozovaných Ústavem fyziky Země. Průměrná hodnota magnituda mb určená v NDC v Brně byla 5,0. Seismologická služba USA (NEIC) udává hodnotu magnituda mb 5,1, podle výsledků zpracování dat v IDC CTBTO ve Vídni dosáhlo magnitudo mb diskutovaného jevu hodnoty 4,8 .

\section{Porovnání severokorejských testů z let 2006, 2009, 2013 a 2016}

Seismická sít Mezinárodního monitorovacího systému CTBTO, včetně stanice VRAC, zaznamenala v posled-

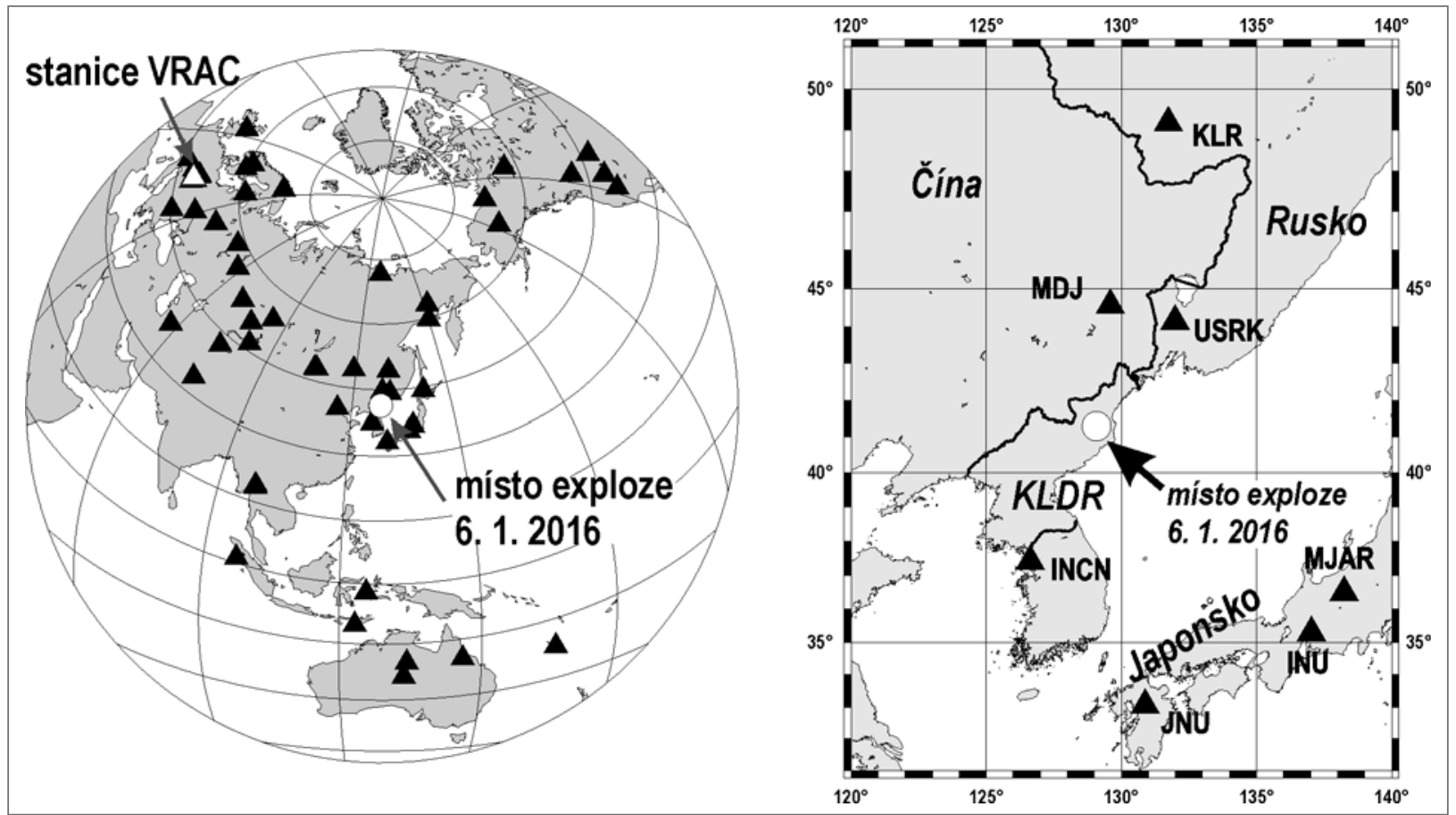

Obr. 1: Schematické mapy umístění epicentra severokorejské jaderné exploze z 6. 1. 2016 v globálním měřítku (vlevo) a v detailnějším výřezu (vpravo): kolečka - epicentrum jaderné exploze; trojúhelníky - pozice stanic využitých v ÚFZ k lokaci exploze (bílý trojúhelník - stanice VRAC; černé trojúhelníky - ostatní stanice).

Fig. 1: Schematic maps of epicentre position of the North Korean nuclear explosion from 6. 1. 2016 in the global scale (left map) and in the regional scale (right map): circles - epicentre of the nuclear explosion; triangles - stations used by IPE for location of nuclear explosion (white triangle - station VRAC; black triangles - other stations). 


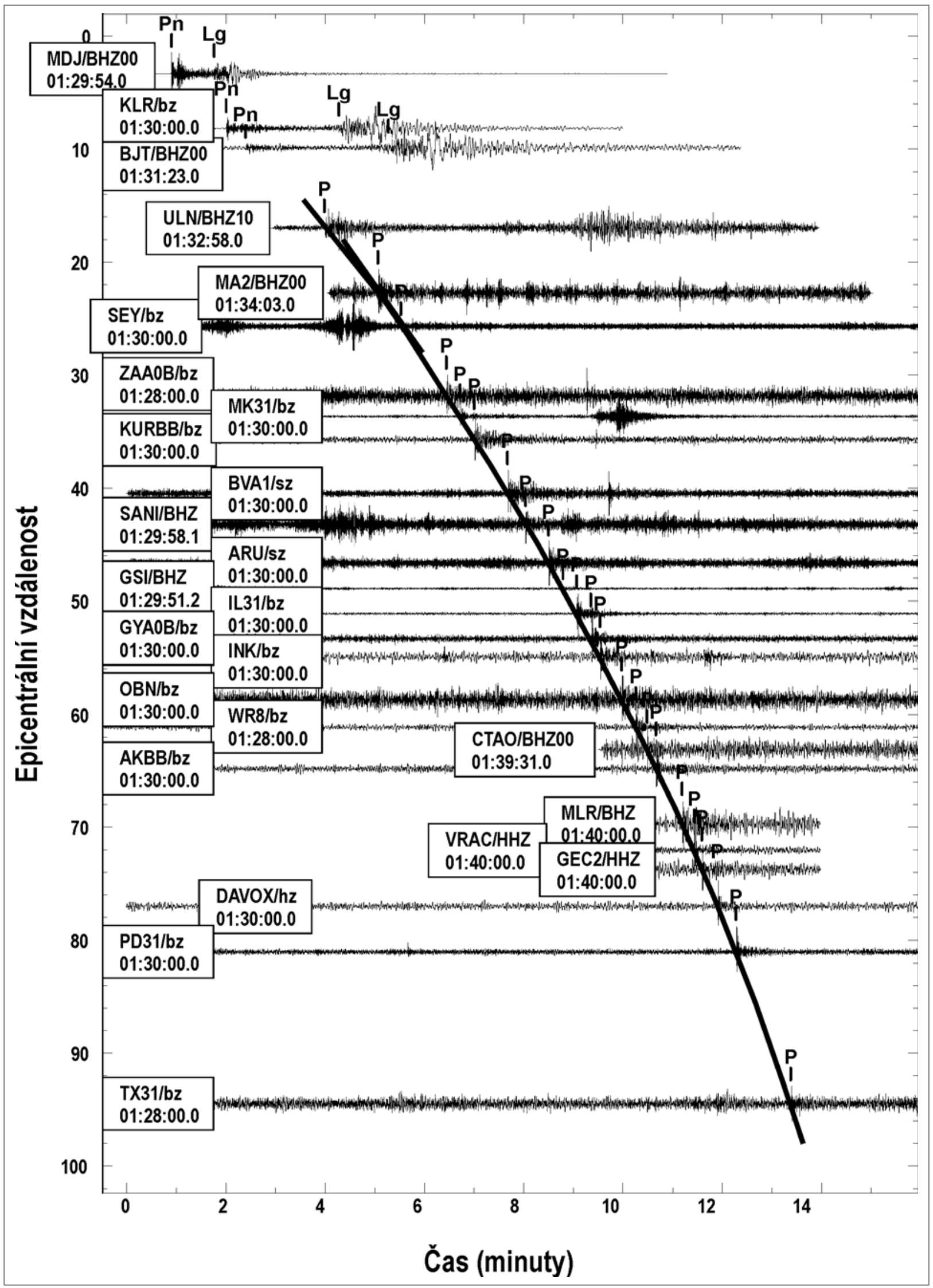

Obr. 2: Záznamy severokorejské jaderné exploze z 6. 1. 2016 na vybraných stanicích využitých v ÚFZ k lokaci exploze (vertikální složka, amplitudy mají nestejná měřítka) vertikálně seřazené v závislosti na epicentrální vzdálenosti stanic. Černou silnou čarou je vyznačena hodochrona podélné vlny $P$.

Fig. 2: Waveforms of North Korean nuclear explosion from 6. 1. 2016 registered by selected stations used by IPE for location this explosion (vertical component, amplitudes are in different scales) vertically arranged in relation to epicentral distances. Black thick line shows the hodochrone of longitudinal wave $\mathrm{P}$. 


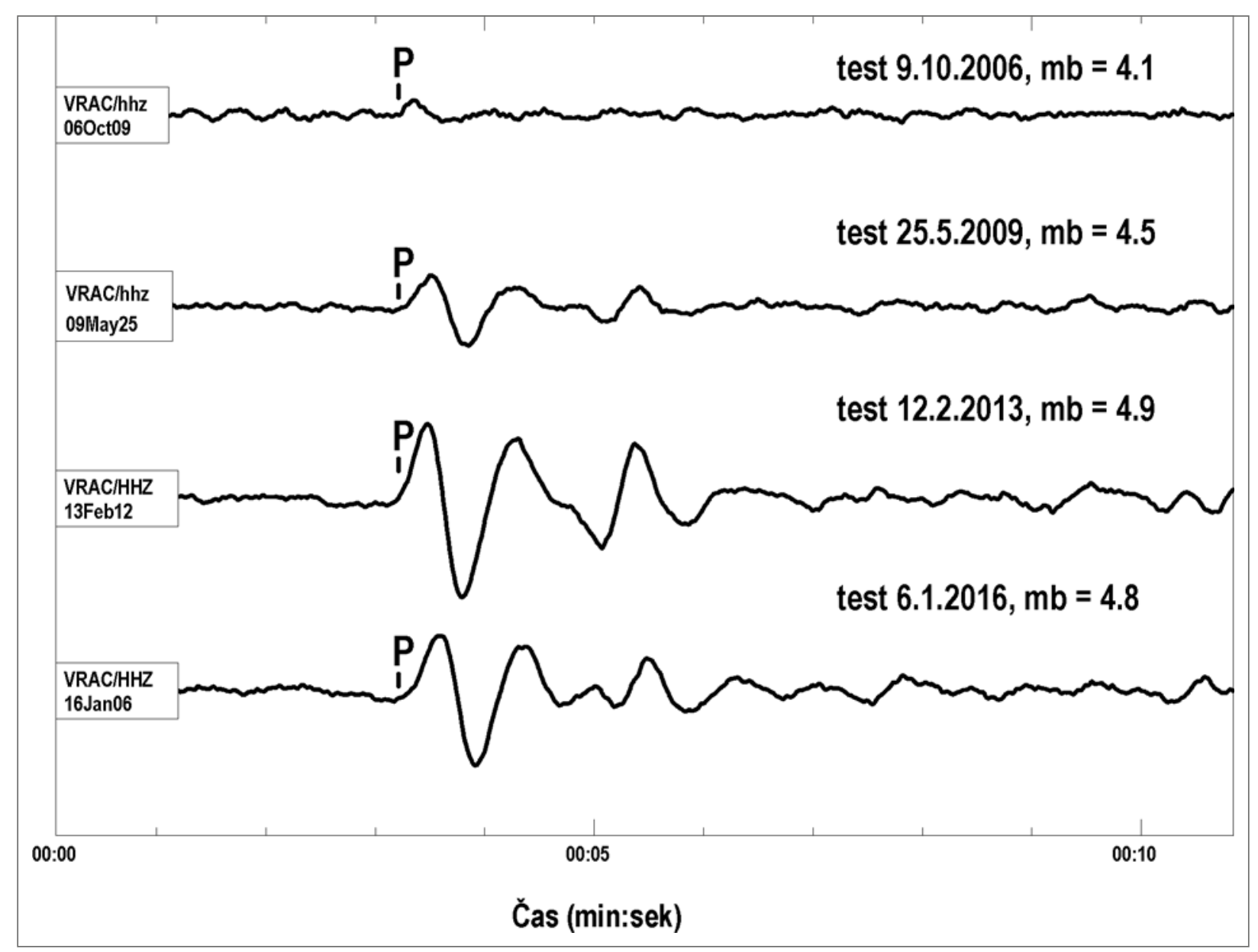

Obr. 3: Záznamy severokorejských jaderných explozí na stanici VRAC (vertikální složka, amplitudy mají stejná měřítka).

Fig. 3: Waveforms of North Korean nuclear explosions registered by station VRAC (vertical component, amplitudes are plotted in same scales).

ním desetiletí celkem čtyři jaderné exploze uskutečněné v Severní Koreji, a to v letech 2006, 2009, 2013 a 2016 (viz obr. 3), prričemž exploze z roku 2006 byla vůbec prvním zaznamenaným jaderným testem provedeným na území KLDR. Epicentra všech čtyř explozí jsou vzájemně blízká, rozdíly mezi nimi se pohybují v řádově kilometrových hodnotách. Malé rozdíly v polohách epicenter explozí byly potvrzeny také studiemi zaměřenými na upřesnění určení polohy s využitím satelitních snímků a dat regionálních seismických sítí (Zhang - Wen 2013). Již tedy jen vysoká podobnost lokace epicentra exploze ze dne 6. 1. 2016 s lokacemi předchozích severokorejských jaderných testů potvrzuje, že daný jev souvisí s činností v místě severokorejského jaderného komplexu Punggye-ri.

Nejslabším z diskutovaných čtyř severokorejských jaderných testů byl test $\mathrm{z} 9$ 9. 10. 2006. Velikost magnituda mb určeného z objemových vln se u této exploze pohybovala mezi hodnotami 4,1 (IDC CTBTO, stejná hodnota byla určena také v NDC Brno) a 4,3 (NEIC). V př́ípadě magnituda mb exploze z 25. 5. 2009 uvádí Mezinárodní datové centrum CTBTO hodnotu 4,5 a seismologická služba USA NEIC hodnotu 4,7. V NDC v Brně byla na základě amplitud odečtených na širokopásmových stanicích ÚFZ vypočtena pro magnitudo mb exploze z 25. 5. 2009 hodnota 4,8. Jaderný test z 12.2. 2013 je representován dosud nejsilnějším seismickým jevem. Jeho magnitudo mb se po- hybovalo mezi hodnotami 4,9 (IDC CTBTO) a 5,1 (NEIC, stejná hodnota byla určena také v NDC Brno). Pro zatím poslední explozi, ze dne 6. 1. 2016, uvádí seismologická služba USA hodnotu magnituda mb 5,1, tedy shodnou s magnitudem určeným pro předešlou explozi z roku 2013. Porovnání amplitud na stanici VRAC (obr. 3) ale ukazuje, že signál odpovídající poslední explozi (6. 1. 2016) je přinejmenším na této stanici evidentně o něco slabší, než signál exploze z roku 2013. Z dat širokopásmových stanic provozovaných ÚFZ bylo pro jaderný test z 6. 1. 2016 určeno magnitudo mb o velikosti 5,0, tedy mírně menší, než hodnota magnituda mb vypočtená v NDC v Brně pro explozi z roku 2013. Tento závěr koresponduje s výsledkem zpracování v IDC CTBTO ve Vídni, které pro explozi z 6. 1.2016 uvádí pro magnitudo mb hodnotu 4,8, tedy rovněž mírně menší oproti magnitudu mb určenému pro předešlý jaderný test $\mathrm{z}$ roku 2013.

\section{Závěr}

Výsledky zpracování záznamů jaderné exploze na severokorejském polygonu Punggye-ri ze dne 6. 1.2016 ukazují dobrou korelaci s předešlými severokorejskými jadernými testy. Velikost exploze byla blízká předešlé explozi z roku 2013, na základě porovnání dat ze stanic Mezinárodního monitorovacího systému CTBTO lze předpokládat, že exploze z roku 2016 byla oproti přešlému 
testu z roku 2013 spíše o něco slabší. Dobrá shoda mezi výsledky získanými nezávisle v Mezinárodním datovém centru CTBTO, v datovém centru seismologické služby USA (NEIC) a v NDC v Brně dokládá vysokou spolehlivost nezávislého určení základních parametrů zdrojů v př́ípadě sledovaných jaderných explozí.

\section{Poděkování}

Přispěvek vznikl s finanční podporou projektu MŠMT, program č. LM2015079, CzechGeo/Epos. Autor děkuje oběma recenzentưm (RNDr. Vladimíru Nehybkovi a Mgr. Tomáši Peckovi) za jejich připomínky.

\section{Poznámka autora:}

V době před konečným tiskem tohoto článku, dne 9.9. 2016, byl uskutečněn na jaderné střelnici Punggye-ri v sv. části KLDR další jaderný test. Magnitudo mb určené z objemových vln této nejnovější exploze se pohybovalo mezi hodnotami 5,1 (CTBTO) a 5,3 (NEIC a NDC Brno), jednalo se tedy zatím o nejsilnější explozi na diskutovaném severokorejském jaderném polygonu. Také seismologická data $\mathrm{z}$ tohoto nejnovějšího testu byla nezávisle zpracována v NDC v Brně, z časových a organizačních důvodů však již nebylo možné detailnější informace o nejnovějším jaderném testu zahrnout do tohoto článku, jehož text byl předložen začátkem r. 2016.

\section{Literatura}

Bowers, D. - Selby, N. D. (2009): Forensic Seismology and the Comprehensive Nuclear-Test-Ban Treaty. - Annual Review of Earth and Planetary Sciences, 37, 209-236.

Havír, J. (2013): Záznamy severokorejských jaderných explozí na seismické stanici VRAC. - Geologické výzkumy na Moravě a ve Slezsku, 20, 1-2, 185-187.

Havír, J. - Švancara, J. - Otruba, J. (2003): Úloha a využití nově certifikované seismologické stanice VRAC v rámci Mezinárodního monitorovacího systému CTBTO. - In: Sborník 12. regionální konference „Nové výsledky seismologických, geofyzikálních a geotechnických průzkumů“. - Sborník vědeckých prací VŠB-TU Ostrava, řada stavební, 3, 2, 77-84.

Hoffmann, W. - Kebeasy, R. - Firbas, P. (1999): Introduction to the verification regime of the Comprehensive Nuclear-Test-Ban Treaty. - Physics of the Earth and Planetary Interiors, 113, 1-4, 5-9.

Zhang, M. - Wen, L. (2013): High-precision location and yield of North Korea's 2013 nuclear test. - Geophysical Reserach Letters, 40, 2941-2946. 